\title{
EATING OUT SEBAGAI GAYA HIDUP (Studi Kasus Fenomena Remaja Kota Banda Aceh di Restoran Canai Mamak KL)
}

\author{
Suci Fajarni \\ Program Studi Sosiologi Agama \\ Universitas Islam Negeri Ar-Raniry Banda Aceh \\ Korespondensi: suci.fajarni@ar-raniry.ac.id
}

\begin{abstract}
Abstrak: Kegiatan konsumsi mendorong seseorang untuk mereproduksi kehidupannya. Kondisi ini berimplikasi pada menjamurnya restoran, café-café, foodcourt, warung kopi, dan berbagai gerai makanan lainnya. Kajian ini diharapkan mampu mengembangkan wawasan terkait dengan perkembangan gaya hidup remaja Kota Banda Aceh yang mendapatkan kepuasan dan kesenangan yang muncul dari aktivitas eating out. Subjek penelitian adalah kaum remaja yang berusia 17 sampai dengan 30 tahun. Secara garis besar, penelitian ini menunjukkan bahwa eating out telah mewujud dalam kehidupan remaja Kota Banda Aceh dan menjadi kegiatan yang sudah biasa dilakukan sehingga menjadi gaya hidup (life style). Ia berhubungan dengan persoalan selera, habitus seseorang, lingkungan,dan interaksi sosial. Eating out juga dapat menjadi arena bertemunya bentuk-bentuk modal, habitus dan praktek sosial remaja.
\end{abstract}

Kata Kunci: Eating Out, Gaya Hidup, Habitus 
Aceh Anthropological Journal, Vol. 3, No. 1, hlm: 21-41, April 2019

\section{A. Pendahuluan}

Kegiatan konsumsi telah menjadi isu penting sejak dasawarsa 1980-an dan semakin mendominasi kehidupan sehari-hari. Saat ini, konsumsi tidak lagi sematamata mewujud sebagai tindakan wajar guna memenuhi kebutuhan biologis seseorang, namun lebih dari itu, konsumsi digunakan sebagai alat komunikasi kepada orang lain untuk menunjukkan posisi sosial, identitas, maupun gaya hidup (Lee: 1993). Senada dengan pandangan tersebut, peneliti mengacu pada pendapat Pierre Bourdieu yang menyatakan, tempat makan dan jenis makanan yang dipilih menentukan kelas sosial seseorang. Sehingga dapat dinyatakan bahwa konsumsi mampu mendorong seseorang untuk mereproduksi kehidupannya.

Salah satu fenomena gaya hidup masyarakat urban adalah aktivitas eating out yang didefinisikan sebagai kegiatan mengkonsumsi makanan yang dilakukan di luar rumah. Fenomena ini mengakibatkan menjamurnya restoran, café-café, foodcourt, warung kopi, serta berbagai gerai makanan lainnya. Tempat-tempat makan tersebut pada akhirnya berkembang menjadi arena pertarungan, tidak saja bagi konsumen dalam menunjukkan status dan kelas sosialnya melalui pemilihan tempat makan serta jenis makanan, namun juga bagi produsen dari segi persaingan untuk menarik minat konsumen dengan menawarkan objek-objek lain selain makanan untuk dapat dikonsumsi.

Fenomena eating out erat kaitannya dengan gaya hidup masyarakat kota yang menggeser budaya makan di rumah. Kegemaran para remaja maupun masyarakat pekerja di Kota Banda Aceh untuk melakukan eating out disebabkan oleh banyak faktor. Salah satunya dimungkinkan karena padatnya rutinitas harian yang dijalani, beragam pilihan tempat makan berupa restoran atau cafe-café yang dapat dengan mudahnya ditemui di setiap sudut kota, faktor keinginan untuk bersosialisasi dan mengisi waktu luang (leisure times), serta faktor variasi dan cita rasa makanan yang disajikan. Selain itu, faktor daya tarik yang ditawarkan restoran atau cafe-cafe seperti desain tempat yang nyaman, lokasi yang strategis, menghadirkan fasilitas penunjang seperti wifi, eksklusivitas dan prestise bagi konsumen turut memupuk kegemaran masyarakat untuk melakukan aktivitas eating out. Eating out juga memiliki batasan, dalam artian tidak semua orang yang makan atau membeli 
Aceh Anthropological Journal, Vol. 3, No. 1, hlm: 21-41, April 2019

makanan diluar rumah dapat dikategorikan sebagai pelaku eating out. Adapun batasan mengenai eating out dikemukakan oleh Warde dan Martens (2003) sebagai berikut:

There are a great many eating out events; eating a packet of crisps or fish sand chips in the street, as well as a sandwich in the office, a barbeque at a friend's house and an elaborate dinner in a restaurant would count, while returning home with a take-away pizza or made-up dish from supermarket would not (Warde dan Martens, 2003: 4).

Pendapat tersebut menjelaskan bahwa sesorang yang membeli makanan di supermarket atau restoran dan kemudian di bawa pulang untuk disantap di rumah tidak termasuk dalam kategori eating out. Seseorang dapat dinyatakan melakukan eating out mencakup makanan yang dibeli serta makanan-makanan yang disiapkan orang lain. Kegiatan tersebut diadakan sebagai sebuah pertemuan yang sifatnya sosial dan spesial yang diiringi dengan menikmati sebuah menu masakan. Lebih lanjut, Warde dan Martens memberikan kategori-kategori untuk mempersempit definisi eating out sehingga muncul definisi praktis yakni sebagai sebuah aktivitas sosiospasial. (Warde dan Martens, 2003: 46).

Eating out sebagai sebuah fenomena memiliki konsep yang melampaui kegiatan konsumsi semata, sebab di dalamnya terkandung aspek sosialisasi dan kesenangan (pleasure). Secara umum, seseorang gemar melakukan eating out dikarenakan aktivitas tersebut telah menjadi bagian dari gaya hidup yang mereka pilih. Gaya hidup yang mampu menandakan identitas dan kelas dari kelompok tertentu. Produsen atau restoran menyajikan pilihan tempat dengan mengusung konsep atau tema tertentu, serta pilihan jenis makanan yang sesuai dengan selera, sehingga tempat makan dan jenis makanan yang dipilih menentukan kelas sosial seseorang. Kebiasaan eating out pada akhirnya dianggap sebagai gaya hidup modern yang muncul sebagai sebuah komoditas masyarakat urban untuk memenuhi kebutuhan sosialisasi mereka, sekaligus sebagai sebuah bentuk hiburan di mana setelah melakukannya mereka berharap dapat merasakan sensasi kesenangan dan kepuasan (Warde dan Martens, 2003: 22-23).

Terdapat berbagai restoran dan café-café yang hadir dengan konsep beragam di Kota Banda Aceh. Salah satunya adalah Restoran Canai Mamak Kuala Lumpur (KL) yang berada di daerah Setui dan Ulee Kareng. Pengunjung restoran ini selalu 
ramai, terutama pada malam hari. Konsep yang ditawarkan oleh restoran ini merupakan bentuk dari Malaysianisitas, yang tidak hanya melihat Malaysia dari sisi kebangsaannya, namun lebih kepada hal-hal yang stereotipikal Malaysia. Misalnya menu-menu yang disajikan seperti roti canai, teh tarik, dan kari, merupakan makanan dan minuman yang lazim ditemukan di Malaysia dan biasanya dijual oleh para mamak (orang India Muslim di Malaysia) yang kemudian menjadikan menumenu tersebut sebagai makanan nasional negara Malaysia. Selain itu, konsep pemesanan makanan di restoran Canai Mamak KL juga telah memanfaatkan teknologi touchscreen seperti pada restoran-restoran di negara maju. Nuansa modern dijadikan strategi untuk mengkomoditaskan eating out dengan merekonstruksi kekhasan suasana, dekorasi ruangan yang menarik, serta cita rasa makanan di mana Malaysianisitas dijadikan sebagai alternatif. Pada akhirnya Malaysianisitas dapat dihubungkan dengan pendapat yang ada di masyarakat selama ini, bahwa apa yang ada di luar Indonesia itu bermakna simbolis sebagai modernitas.

Eating out bukan sesuatu yang berasal secara alamiah atau bakat alam seseorang, akan tetapi terbentuk karena hubungan kekuasaan, sosial dan budaya serta bagaimana hubungan tersebut mempengaruhi dalam membentuk kepribadian seseorang. Dengan kata lain, proses konsumsi yang mencerminkan gaya hidup dan selera budaya lebih pada praktek yang membantu memberikan pemahaman bagi seorang individu maupun orang lain mengenai posisi mereka dalam ruang sosial yang disebabkan adanya dominasi kelas yang kemudian ditiru kelompok masyarakat lain untuk mendapatkan pengakuan sederajat (setara). Hal ini sesuai dengan pernyataan Pierre Bourdieu dalam karyanya yang berjudul "Distinction" yang menjelaskan bahwa "gaya hidup terbentuk karena sebuah pilihan yang berhubungan selera, posisi seseorang dan sistem klasifikasi kelas dalam ruang sosial" (Bordieu, 1984: 175).

Faktor lainnya adalah gaya hidup (life style) dapat dipengaruhi oleh habitus yang bersifat individual, "life styles are thus the systematic products of habitus" (Bordieu, 1984: 178). Hal ini juga berkaitan dengan selera, lingkungan sosial dan kepemilikan modal. Tindakan memilih suatu jenis makanan atau tempat makan tertentu mereka gunakan untuk membuat distingsi berdasarkan selera masing- 
masing. Sebagai contoh, posisi tertentu (misalnya orang kaya), cenderung menghasilkan habitus metropolis seperti selera, cara makan, gaya berpakaian, gerak-gerik tubuh, dan lain sebagainya yang berbeda jika dibandingkan dengan habitus orang miskin. Habitus melekat sejak lahir yang kemudian berkembang seiring dengan meluasnya relasi pelaku dengan pelaku lain yang berbeda habitusnya. Oleh karena itu, prosesi eating out mampu menciptakan diferensiasi sosial yang mengakibatkan berkembangnya berbagai gaya hidup.

Restoran Canai Mamak KL baik yang berlokasi di daerah Setui maupun Ulee Kareng selalu ramai dikunjungi konsumen, terutama pada malam hari. Adapun aktifitas yang sering dilakukan para pengunjung restoran setelah menyantap makanan dan minuman adalah tetap berada dikursi mereka sambil melanjutkan perbincangan dengan teman atau rekan kerjanya dan beberapa pengunjung juga terlihat melakukan foto bersama. Pengunjung memanfaatkan tempat dan suasana yang hangat yang tercipta di restoran tersebut untuk melakukan interaksi sosial. Artinya, kehadiran mereka di restoran tersebut tidak hanya terbatas pada aktivitas mengkonsumsi makanan dan minuman semata. Pengunjung yang datang ke restoran tersebut terdiri dari pegawai kantoran yang rata-rata berusia antara 20-30 tahun, keluarga, dan sebagian besarnya terdiri dari remaja (baik pelajar atau mahasiswa) yang datang bersama teman-temannya.

Berdasarkan gambaran tersebut, penelitian ini bertujuan untuk menganalisa "Bagaimana eating out menjadi gaya hidup di kalangan remaja Kota Banda Aceh". Penelitian ini menekankan kepada dinamika gaya hidup remaja guna melihat secara lebih dalam seperti apa kegiatan eating out yang khas dilakukan remaja. Alasan pemilihan remaja sebagai subjek penelitian dikarenakan kaum remaja memiliki intensitas yang lebih sering untuk berkunjung ke restoran tersebut.

Adapun pemilihan subjek penelitian didasarkan pada definisi remaja yang digunakan oleh Hurlock (1990) yang membagi masa remaja menjadi dua jenjang, yaitu: masa remaja awal (13 hingga 16 atau 17 tahun) dan masa remaja akhir (17 hingga 20 tahun). Pada masa remaja akhir, individu telah mencapai transisi perkembangan yang lebih mendekati masa dewasa, sehingga pada usia 17 sampai 20 tahun remaja sedang berusaha membentuk citra (image) tentang dirinya seperti mempersepsikan dirinya, menampilkan diri secara fisik sehingga mendorong 
Aceh Anthropological Journal, Vol. 3, No. 1, hlm: 21-41, April 2019

mereka untuk melakukan berbagai upaya agar tampilan fisiknya sesuai dengan tuntutan komunitas sosial mereka.Berdasarkan penjelasan tersebut, dengan mempertimbangkan target utama restoran Canai Mamak yang merupakan remaja dan pekerja kantoran (Mirnawati, 2001). Akhirnya peneliti memilih kaum remaja yang berusia 17 sampai dengan 30 tahun untuk menjadi subjek penelitian.

Penelitian ini diharapkan mampu mengembangkan wawasan terkait dengan perkembangan gaya hidup remaja Kota Banda Aceh yang mendapatkan kepuasan dan kesenangan yang muncul dari aktivitas eating out.

\section{B. Metode Penelitian}

Metode yang digunakan dalam penelitian ini adalah metode penelitian kualitatif di mana metode ini dipengaruhi oleh paradigma naturalistik-interpretatif Weberian, perspektif post-positivistik, kelompok teori kritis serta post-modernisme seperti dikembangkan oleh Baudrillard, Lyotard dan Derrida (Cresswell, 1994). Metode kualitatif berusaha untuk mengangkat secara ideografis berbagai fenomena dan realitas sosial yang terjadi. Penelitian ini bersifat deskriptif yang mendeskripsikan bagaimana fenomena eating out dapat menjadi gaya hidup remaja kota Banda Aceh yang direlasikan dengan konsumsi ruang (space) dan tempat (place) pada kasus restoran Canai Mamak KL.

Adapun jenis data dalam penelitian ini adalah data primer dan data sekunder. Data primer diperoleh peneliti dari hasil wawancara yang dilakukan kepada subjek penelitian yang melakukan aktivitas eating out pada dua restoran Canai Mamak KL yang berada di daerah Setui dan Ulee Kareng, sedangkan data sekunder yang digunakan adalah data-data yang berhubungan dengan objek penelitian yaitu restoran Canai Mamak KL, terkait juga dengan penggunaan teori yang diperoleh melalui beberapa referensi seperti buku, jurnal, literatur, data pada beberapa website, maupun sumber-sumber tertulis lainnya.

Teknik pengumpulan data dilakukan melalui cara wawancara mendalam (indepth interview) dan observasi. Wawancara mendalam dijadikan sebagai sumber data utama pada penelitian ini sebagai proses untuk memperoleh keterangan dari informan yang menjadi subjek penelitian. Sedangkan teknik observasi dijadikan sumber data pendukung yang digunakan untuk menyajikan gambaran nyata terkait 
suasana dan gambaran mengenai konsep yang diusung restoran Canai Mamak KL sebagai objek dalam penelitian ini.

Selanjutnya, analisis data dilakukan dengan teknik deskriptif kualitatif guna mengelaborasi data yang telah peneliti peroleh dari hasil wawancara dan observasi secara sistematis. Hal pertama yang dilakukan adalah memetakan kerangka pemikiran mengenai eating out sebagai gaya hidup, dengan memfokuskan penelitian pada konsumsi ruang dan tempat di restoran Canai Mamak KL. Kedua, mengumpulkan data, mengidentifikasi subjek penelitian (yang terdiri dari 8 orang informan; 4 remaja (terdiri dari karyawan swasta) merupakan pelaku eating out di restoran Canai Mamak KL daerah Setui dan 4 remaja lainnya (terdiri dari mahasiswa) merupakan pelaku eating out di restoran Canai Mamak KL daerah Ulee Kareng). Subjek penelitian diklasifikasikan berdasarkan usia, pendidikan, pekerjaan, status ekonomi sosial, dan intensitas berkunjung ke restoran tersebut, kemudian menggali perspektif mereka tentang eating out yang telah terangkum dalam pertanyaan wawancara. Data yang telah terkumpul kemudian diolah, dianalisis dan dielaborasikan dengan teori dan konsep-konsep yang kemudian menghasilkan penjelasan mengenai fenomena eating out yang telah menjadi gaya hidup remaja kota Banda Aceh khususnya pada kasus yang terjadi di restoran Canai Mamak KL.

\section{Landasan Teori}

\section{Eating Out}

Kebiasaan eating out telah lama menjadi kajian para ahli, khususnya di Perancis, Amerika Serikat, dan Inggris. Di Inggris, studi mengenai eating out dilakukan oleh Alan Warde dan Lydia Martens (2003). Mereka melihat kebiasaan eating out yang dilakukan anggota masyarakat tergabung dalam beberapa kelas, yaitu kelas atas, menengah, dan pekerja. Mereka sampai pada kesimpulan bahwa berdasarkan survei yang mereka lakukan tersebut, masyarakat perkotaan di Inggris mendapatkan sensasi kesenangan (pleasure) dan kepuasaan dari kegiatan eating out.

Warde dan Martens (2003: 43) memberikan definisi awal eating out sebagai "the consumtion of all foods taking place outside one's own household". Definisi ini 
memberikan batasan pengecualian terhadap beberapa kondisi agar eating out menjadi lebih mudah dipahami. Beberapa pengecualian tersebut adalah makanan yang dibeli namun dibawa pulang untuk dikonsumsi di rumah, makanan yang disajikan oleh perusahaan catering pesta, serta makanan ringan seperti keripik dan buah-buahan yang dimakan di pinggir jalan. Ciri-ciri yang terdapat dalam pengertian awal ini beserta beberapa pengecualian menunjukkan penekanan Warde dan Martens pada aspek spasial (dimana seseorang makan).

Eating out telah menjadi sebuah aktivitas sosial dan berkembang pula menjadi gaya hidup di kalangan remaja. Dalam studi yang dilakukan oleh Warde dan Martens disebutkan terdapat beberapa faktor yang mempengaruhi tingginya frekuensi akses terhadap eating out, yaitu: (1) usia yang masih muda; (2) memiliki pendapatan rumah tangga yang cukup (untuk melakukan eating out); (3) berada di satus sosial tertentu; (4) belum memiliki pasangan; (5) tidak memiliki anak di bawah 16 tahun. (Warde dan Martens, 2003: 71).

Adapun alasan utama melakukan eating out adalah seseorang akan mendapatkan pengalaman yang berbeda dari aktivitas harian yang terpola, dapat beristirahat sejenak dari aktivitas memasak ataupun menyajikan masakan di rumah, dapat bersantai, bersosialisasi, merayakan sesuatu, mentraktir, senang dengan sebuah masakan, dan mencegah kelaparan. (Warde dan Martens, 2003: 47).

Pada umumnya, kesenangan dicapai oleh konsumen ketika mereka mendapatkan kepuasan dalam proses konsumsi berupa meterial masakan yang berhubungan dengan selera, pelayanan, dan kesan spesifik yang diciptakan oleh tempat makan yang mereka kunjungi. Warde dan Martens juga menyatakan bahwa kondisi tempat makan (seperti suasana yang nyaman dan "bikin betah") menjadi salah satu faktor penentu munculnya sensasi kesenangan pada konsumen. Disisi lain, konsumen juga memperhatikan rasa dan porsi makanan yang disajikan. Dalam penelitian tersebut dijelaskan gambaran pengalaman yang didapatkan dari para konsumen ketika melakukan eating out yaitu: "nice", "really nice", "very nice", "good", "enjoyable", "lovely", "fabulous", "I loved it", dan "I like it". (Warde dan Martens, 2003: 191). Ungkapan-ungkapan tersebut merupakan respon yang umum dikatakan oleh konsumen bila rasa makanan dan suasananya sesuai dengan harapan mereka. 
Faktor lain yang ikut mendorong terciptanya sensasi kesenangan pada konsumen yang senang melakukan kegiatan eating out adalah sosialisasi. Warde dan Martens menemukan bahwa bagi sebagian orang, kegiatan eating out memang sengaja dilakukan untuk menciptakan proses sosialisasi di luar kegiatan sehari-hari, entah di lingkungan tempat tinggal atau lingkungan tempat kerja. Sosialisasi sebagai tujuan membuat faktor-faktor lain menjadi lebih kecil perannya dalam penciptaan sensasi kesenangan pada konsumen. Bahkan, jika makanan yang disajikan tidak dapat memberikan kesan baik, maka sosialisasi dapat mengobatinya.

\section{Distingsi dan Habitus}

Pierre Bordieu berpendapat bahwa distingsi dapat muncul dari pilihan dan konsumsi seseorang terhadap sesuatu, ini berarti bahwa seseorang ingin terlihat berbeda dari orang lain. Hal ini dapat diamati dari beragam aspek, misalnya pilihan merek barang yang digunakan, genre musik yang didengarkan, bahkan jenis makanan yang dikonsumsi pun dapat menunjukkan selera dan gaya hidup (life style) seseorang.

"Bordieu argues that it is taste rather than high or low income which structures the practices associated with consuming such resources, and that depending on one's position within a system based on identifying oneself with a social group and distinguishing oneself from others, this generates a set of 'choices' that constitute life styles" (Bordieu, 1984: 175).

Bagi Bourdieu, berbicara mengenai persoalan selera dan pilihan budaya, tidak akan bisa dipisahkan dari persoalan latar belakang budaya individu-individu yang bersangkutan. Latar belakang budaya juga tidak dapat dilepaskan dari jenis pekerjaan, jenis kelamin, tempat tinggal, kelas sosial, hingga latar belakang orang tua individu yang bersangkutan. Faktor-faktor tersebut jugalah yang nantinya akan berpengaruh pada gaya hidup yang dimiliki oleh seseorang.

Gaya hidup menurut Kotler (2002: 192) merupakan pola hidup seseorang di dunia yang diekspresikan dalam aktivitas, minat, dan opininya. Senada dengan pendapat tersebut, Assael (1984) menyatakan bahwa gaya hidup adalah "A mode of living that is identified by how people spend their time (activities), what they consider important in their environment (interest), and what they think of themselves and the world around them (opinions)". Di mana gaya hidup dikenali dengan bagaimana 
orang menghabiskan waktunya (aktivitas), apa yang penting dipertimbangkan orang pada lingkungannya (minat), dan apa yang orang pikirkan tentang diri mereka sendiri serta dunia di sekitarnya (opini).

Menurut Mike Feeatherstone (2005), dalam budaya konsumen kontemporer, istilah gaya hidup mengkonotasikan individualitas, ekspresi diri, serta kesadaran diri yang stilistik. Lebih lanjut dikatakan bahwa tubuh, pakaian, pilihan liburan, hiburan saat waktu luang, dan seterusnya dipandang sebagai indikator dari individualitas selera serta rasa gaya dari pemilik atau konsumen. Persoalan gaya hidup erat kaitannya dengan persoalan selera, habitus, konsumsi, dan identitas. Seseorang memutuskan untuk memilih sesuatu sesuai dengan seleranya dan berbeda dengan orang lain, berarti ia dapat juga mengartikulasikan kelas, latar belakang, dan identitas budayanya. Berdasarkan penelitian yang dilakukan di Perancis pada tahun 1960-an, Bordieu menyatakan bahwa selera dapat menciptakan fraksi kelas. Penelitian tersebut menunjukkan bahwa selera makan dan perbedaan praktek kelas memiliki makna karena berhubungan dengan logika budaya kelas dan perjuangan untuk kekuasaan budaya antar kelas tertentu (Bordieu, 1984: 144).

Menurut teori Baudrillard, logika konsumsi masyarakat kini bukan lagi berdasarkan nilai guna (use value) atau nilai tukar (exchange value) seperti yang dikemukakan oleh Karl Marx, melainkan hadir nilai baru yang disebut nilai simbolis (symbolic value). Rasionalitas konsumsi masyarakat kini telah jauh berubah. Saat ini masyarakat berkonsumsi bukan lagi sebagai upaya untuk pemenuhan kebutuhan (needs) semata, namun lebih sebagai pemenuhan hasrat (desire). Kebutuhan mungkin dapat dipenuhi dengan konsumsi objek. Namun sebaliknya, hasrat justru tidak akan pernah terpenuhi.

Seperti yang dikatakan Baudrillard, "The law of seduction takes the form of an uninterrupted ritual exchange where seducer and seduced constatntly raise the stakes in a game that never ends" (Baudrillard,1990). Masyarakat konsumen pada saat ini mengkonsumsi simbol-simbol yang melekat pada suatu objek, sehingga objek-objek konsumsi banyak yang terkikis nilai guna dan nilai tukarnya. Nilai simbolis kemudian menjadi komoditas. Konsumsi tidak lagi dinilai dari aspek fungsi, namun 
Aceh Anthropological Journal, Vol. 3, No. 1, hlm: 21-41, April 2019

diambil alih oleh simbol yang telah melewati proses simulasi sehingga mengaburkan fungsi itu sendiri.

Distingsi erat kaitannnya dengan persoalan habitus yang merupakan seperangkat sifat yang dapat melahirkan praktek dan persepsi. Dapat juga dianggap sebagai logika permainan yang mendorong agen-agen bertindak dan bereaksi dalam situasi-situasi spesifik dengan suatu cara yang tidak selalu bisa diprediksi sebelumnya. Bordieu menyatakan bahwa konsep habitus merupakan suatu sistem yang terkonstruksi secara sosial (Bordieu, 1977: 76). Artinya habitus yang dimiliki oleh seseorang dapat berbeda dengan orang lain, tergantung pada siapa yang melakukan internalisasi dan bagaimana prosesnya. Mark Paterson pernah melakukan pembacaan atas karya Bordieu "Distinction" yang terdapat dalam bukunya "Consumption and Everyday Life" bahwa:

"Connecting up these notions of consumer choice, brand and cultural identity it will be useful initially to look at the work of Pierre Bordieu, whose book Distinction (1986a) provides a sociologycal analysis of the way that social groups form and maintain their identities by a process of distinguishing themselves from others, this process of distinction being performed through acts of consumption" (Paterson, 2006: 39).

Berbicara mengenai gaya hidup, terkadang sebagian orang hanya ikut-ikutan guna meraih kesetaraan dengan teman-teman di lingkungan sosialnya. Mereka melakukannya dengan sadar, dalam jangka waktu yang lama dan bertujuan agar dapat diterima dalam komunitas yang ditiru, Bahkan ada pula yang sampai memaksakan diri. Hal tersebut membuktikan bahwa gaya hidup tidak dapat dipisahkan dari distingsi dan habitus.

\section{Eating Out Sebagai Gaya Hidup (life style)}

Setiap orang memiliki interpretasi beragam terkait dengan aktivitas eating out. Satu hal penting dari aktivitas ini adalah kebersamaan dalam kondisi tertentu yang dapat mengilustrasikan kepemilikan secara sosial dan keintiman antara sesama pelaku aktivitas tersebut. Melalui makanan mereka dapat berinteraksi, menikmati obrolan, dan mencapai kesenangan secara bersama. Berdasarkan hasil wawancara, peneliti menyimpulkan bahwa remaja pelaku eating out di restoran 
Canai Mamak KL mempunyai pemahaman yang sama terkait dengan konsep eating out yang digunakan dalam penelitian ini, yaitu:

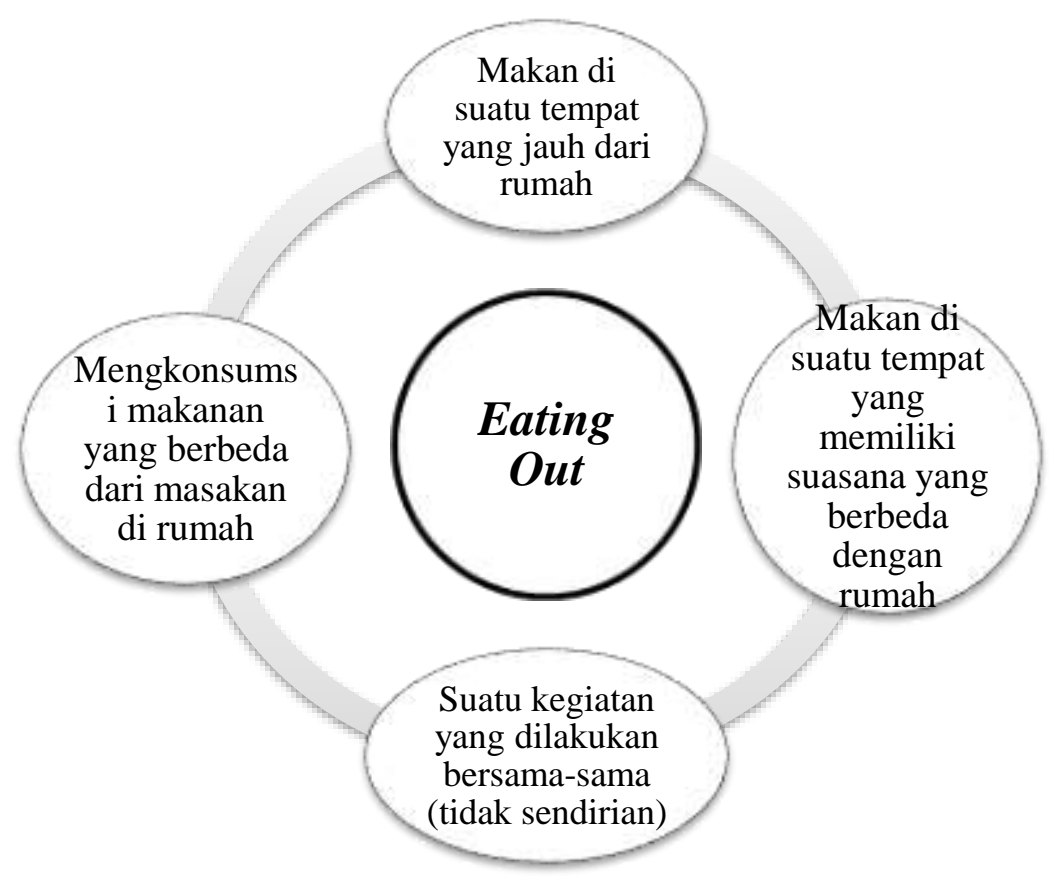

Pelaku eating out di restoran Canai Mamak KL melakukan aktivitas tersebut secara berkelompok yang terdiri dari 3 orang atau lebih. Ketika menunggu pesanan disajikan, remaja-remaja tersebut berinteraksi dengan sesamanya. Alasan umum mereka melakukan eating out adalah ingin mencari suasana makan yang berbeda dengan rumah (baik dari segi menu maupun suasana tempat) sekaligus menjadi ajang berkumpul dan bersosialisasi bersama teman-teman setelah seharian bekerja atau sekolah. Eating out kemudian menjadi sebuah alternatif yang berkaitan dengan selera individu yang berlanjut menjadi gaya hidup para remaja tersebut.

Terkait dengan intensitas para remaja pelaku eating out, berdasarkan pernyataan dari beberapa informan, mereka menyatakan bahwa 2 hingga 3 kali dalam seminggu mereka mewajibkan diri untuk melakukan eating out dengan kelompok pergaulannya guna menjaga solidaritas antara sesama mereka yang tidak bisa bertemu setiap harinya, baik disebabkan oleh jenis pekerjaan yang berbeda (bagi pekerja/ karyawan), ataupun setelah penat dengan aktivitas belajar (untuk kasus remaja yang masih berstatus sebagai mahasiswa atau pelajar). Hal ini kemudian peneliti kaitkan dengan aspek-aspek pemikiran dari Pierre Bordieu yang menjadi landasan teori dalam penelitian ini. 
Adapun aspek pertama merupakan habitus yang berelasi dan dapat menjadi penentu terhadap gaya hidup yang dianut seseorang. Habitus menurut Bordieu merupakan suatu sistem yang terkonstruksi secara sosial, berisi tentang struktur yang berasal dari proses pengasuhan dan pendidikan dalam masyarakat. Habitus berhubungan erat dengan realitas sosial. Dalam hal ini, seseorang yang memilih gaya hidup tertentu merupakan agen dengan habitus tertentu. Dalam hal ini Bordieu menempatkan seseorang sebagai subjek yang memiliki otonomi dalam dirinya sehingga dapat menentukan pilihan masing-masing (Harker, Mahar, dan Wilkes, Eds. Terj. Pipit Maizier, 2009: xix). Pengalaman hidup dan latar belakang dari agen tersebut kemudian membentuk habitusnya, sehingga ia mengalami internalisasi pada saat mengaplikasikan gaya hidup yang telah dipilih. Habitus sudah tidak lagi berada pada tingkat kesadaran (conciousness) dan menjadikannya sebagai suatu hal alamiah atau taken for granted. Maka habitus dapat dinyatakan sebagai wujud ketidaksadaran kultural yang merupakan produk dari proses adaptasi, karena bukan berasal dari pengetahuan bawaan yang memiliki motivasi tertentu.

Habitus terbentuk melalui proses pengasuhan, aktivitas sehari-hari dan pendidikan dalam masyarakat (Harker, Mahar, dan Wilkes, Eds. Terj. Pipit Maizier, 2009: xviii). Saat para remaja tersebut melakukan eating out, ia tidak lagi merasa canggung dan tidak menganggap hal tersebut berada di luar dirinya, karena habitus yang telah menjadi bagian dari hidupnya. Habitus selain sebagai suatu sistem watak yang berlangsung lama dan berubah-ubah juga berfungsi sebagai basis generatif bagi praktek-praktek yang terstruktur dan terpadu secara objektif. Ranah merupakan suatu area yang secara tidak langsung mengatur posisi seseorang dalam masyarakat (Harker, Mahar, dan Wilkes, Eds. Terj. Pipit Maizier, 2009: xvii-xviii). Kemudian muncul semacam analogi sebagai berikut:

$($ HABITUS $\times$ MODAL $)+$ RANAH $=$ PRAKTEK

Secara garis besar, analogi tersebut menjelaskan hubungan antara habitus, modal dan ranah. Sedangkan praktek tidak hanya menunjukkan habitus seseorang saja, namun lebih kepada relasi antara habitus dengan kondisi terkini (Bordieu \& Wacquant dalam Grenfell, 2008: 52). Analogi tersebut dapat menjelaskan bahwa remaja yang melakukan praktek eating out selalu berhubungan dengan persoalan 
habitus, modal yang dimiliki, ranah (tempat) ia berada, dan dengan siapa ia menjalin relasi. Keempat aspek tersebut saling berhubungan dan dapat berbeda antar satu individu dengan individu lainnya.

Aspek kedua adalah modal. Bagi Bordieu, modal bersifat cair, dinamis dan bukan sesuatu yang selalu dapat dihitung dengan angka.

"The definition of capital is very wide for Bordieu and includes material things (which can have symbolic value), as well as "untouchable" but culturally significant attributes such as prestise, status and authority (referred to as symbolic capital along with cultural capital (defined as culturally valued taste and consumption patterns)... For Bordieu, capital acts as a social relation within a system of exchanged and the term is extended"to all the goods, material and symbolic, without distinction, that present themselves as rare and worthy of being sought after in a particular social formation" (Harker, Mahar, dan Wilkes dalam Schirato dan Danaher, 2002: 22).

Berdasarkan definisi tersebut, penelitian ini menunjukkan bahwa penyebab remaja kota Banda Aceh melakukan eating out tidaklah sekedar untuk memenuhi kebutuhan biologis (mengkonsumsi makanan) semata, namun juga berelasi dengan modal ekonomi, modal kultural, modal sosial, dan modal simbolik. Modal ekonomi yang mereka miliki merupakan penghasilan tetap yang cukup untuk memenuhi selain kebutuhan primer. Hal ini memungkinkan mereka untuk bebas memilih tempat makan untuk menikmati waktu luang (leisure time). Sebagai contoh, Adil (25 tahun), Desi (25 tahun), dan Nisa (26 tahun), tiga orang remaja yang bekerja di perusahaan Swasta yang berbeda. Adil merupakan staf pemasaran pada salah satu dealer kendaraan roda empat, sedangkan Desi dan Nisa bekerja merupakan karyawan bank Swasta yang berbeda. Ketiganya telah bersahabat dan saling mengenal sejak dari bangku kuliah. Mereka berada di ranah pekerja yang sibuk dan jarang memiliki waktu luang, sehingga memendam kerinduan akan waktu luang. Bagi remaja dengan modal ekonomi yang cukup seperti ketiganya, menjadi tidak merasa bersalah untuk mengalokasikan sebagian penghasilan mereka guna menikmati makanan yang nikmat sekaligus suasana restoran yang nyaman dan sesuai dengan selera mereka. Di mana selera dalam hal ini merupakan pilihanpilihan yang mereka buat dan termanifestasikan (dalam tindakan budaya). Ia 
merupakan sebuah afirmasi atau penegasan dari sebuah perbedaan yang tak terelakkan (Bourdieu, 1984: 56).

Adapun modal sosial, merujuk kepada posisi Adil, Desi dan Nisa di lingkungan sosial mereka masing-masing. Modal sosial dapat disimpulkan dari obrolan yang mereka lakukan ketika menunggu pesanan makanan disajikan di restoran Canai Mamak KL daerah Setui. Salah seorang dari mereka yang bernama Adil membicarakan rencananya berkunjung ke Singapura pada akhir Desember mendatang untuk meramaikan acara pergantian tahun baru 2016. Saat memberitahukan rencana tersebut kepada teman-temannya, Adil menekankan kembali bahwa negara yang dituju adalah Singapura (tidak dilakukan di dalam negeri/ Indonesia). Berdasarkan asumsi dari peneliti, penekanan tersebut mengarah kepada keingingan Adil untuk menunjukkan identitas dan kelas sosial di mana ia berada. Pilihan tertentu menjadi penanda atau simbol dari sebuah kelas sosial tertentu pula. Kelompok dari kelas sosial yang tinggi cenderung menunjuk selera yang berbeda dengan kelas sosial yang lebih rendah.

Modal kultural merupakan sebuah wujud pengetahuan yang telah mengalami proses internalisasi ke dalam diri atau perolehan kognitif yang melengkapi agenagen sosial dengan empati, kompetensi relasi-relasi dan artefak-artefak kultural (Bordieu, 1984: 2). Modal kultural berhubungan dengan latar belakang pendidikan, kemampuan dan kompetensi diri. Sebagai contoh Fitri (25 tahun), salah seorang subjek dalam penelitian ini. Modal kultural yang dimiliki Fitri yaitu: ia merupakan lulusan dari Universitas Syiah Kuala Banda Aceh, Jurusan Bahasa Inggris yang saat ini bekerja di beberapa tempat sekaligus, pertama sebagai penyiar pada salah satu Stasiun Radio Swasta di Kota Banda Aceh dan mengajar pada salah satu English School untuk anak-anak usia dini yang berlokasi di pusat Kota Banda Aceh. Fitri berada di dalam lingkungan tempat kerja yang menuntut untuk berpenampilan rapi dan mobilitas tinggi. Modal simbolik ditunjukkan dengan kepemilikan berbagai perangkat komunikasi yang digunakan untuk mendukung kelancaran dalam bekerja. Fitri pun dituntut untuk selalu mobile dan berkoordinasi dengan orangorang yang berada pada dua tempat berbeda yang menjadi tempatnya bekerja. Mobilitas sosial yang tinggi dipengaruhi oleh padatnya jadwal kerja Fitri menyebabkan ia jarang memiliki kesempatan untuk makan di rumah dan tidak 
memiliki waktu memasak karena kelelahan. Sehingga kegiatan eating out sering dilakukannya bersama dengan teman-teman sekantornya. Selain sebagai sarana pemenuhan kebutuhan biologis, Fitri mengaku bahwa aktivitas eating out juga dilakukannya untuk melepas penat sekaligus memperoleh kesenangan (pleasure) dengan melakukan interaksi dengan sesama teman-temannya setelah disuguhi kepadatan aktivitas yang dialaminya setiap hari. Dalam hal ini, eating out telah menjadi sesuatu yang alamiah pada diri Fitri dan pada akhirnya menjadi bagian dari dirinya.

Adapun modal simbolik ditemukan ketika peneliti melakukan observasi pada salah satu meja dengan 4 orang mahasiswa Universitas Syiah Kuala yang sedang melakukan eating out di restoran Canai Mamak KL di daerah Ulee Kareng. Hal tersebut dapat dilihat dari kepemilikan berbagai jenis gadget yang diletakkan di atas meja mereka ketika sedang melakukan aktivitas eating out. Selain itu, mereka juga menggunakan aksesoris seperti cincin, gelang, tas dan sepatu bermerek (branded), sehingga dapat menyiratkan bahwa secara simbolik mereka memang memiliki modal, berasal dari keluarga menengah ke atas, dan mengikuti perkembangan tren teknologi maupun fashion. Kolektifitas eating out ini kemudian menempatkan mereka pada posisi dominan yang membedakan dirinya dengan masyarakat lain dengan gaya dan cara menampilkan selera yang sah dan cenderung menunjukkan eksistensi di lingkungan sosialnya untuk diakui orang lain.

Berdasarkan temuan-temuan tersebut, hasil penelitian ini menjelaskan bahwa eating out telah dijadikan sebagai gaya hidup. Mengapa? Karena peneliti menemukan bahwa gaya hidup juga berelasi dengan persoalan selera secara individu. Sesuai dengan konsep Bordieu tentang keterkaitan antara habitus, modal, ranah, dan praktek, gaya hidup merupakan salah satu produk sistematis dari habitus yang dapat dirasakan dalam hubungan bersama, menghasilkan sistem tanda dan mengalami kualifikasi secara sosial. Gaya hidup dapat digunakan untuk membedakan diri dengan orang lain karena bergantung kepada bentuk kultural yang dimiliki oleh masing-masing individu. Ketika seseorang memilih gaya hidup tertentu, ia dapat menunjukkan dan menegaskan identitas dirinya secara sosial.

Terkait dengan hal itu, Chaney (1996) menjelaskan ciri baru dari identitas sosial yang terdiri dari tiga tahap. Pertama, disampaikan dengan menggunakan 
Aceh Anthropological Journal, Vol. 3, No. 1, hlm: 21-41, April 2019

istilah pilihan. Sebagai contoh, pemilihan restoran Canai Mamak KL sebagai simbol modernitas menjadi alasan mengapa para informan cenderung memilih restoran ini untuk melakukan aktivitas eating out daripada memilih restoran selain restoran tersebut. Kedua, pilihan tersebut terjadi di dalam kehidupan seseorang dan merupakan bagian dari pemanfaatan waktu luang. Contohnya, setelah kuliah atau bekerja seharian, para remaja menghabiskan waktu luangnya (dari sore hingga malam) dengan melakukan eating out di sebuah restoran. Ketiga, selera yang awalnya bersifat personal pada akhirnya akan tetap terjebak ke dalam pola khusus dan menghubungkan mereka dengan karakteristik sosiokultural lainnya. Selera atau cita rasa berperan sebagai landasan utama dalam pembentukan sebuah gaya hidup, ia dapat bekerja secara subjektif dan objektif. Selera mengandung unsur khusus yang dapat membedakan antara seseorang dengan yang lainnya. Jika dikaitkan dengan pemikiran Bordieu, persoalan selera dan pilihan budaya terbentuk melalui relasi-relasi kekuasaan, sosial dan kultural serta bagaimana relasi-relasi tersebut mempengaruhi dan membentuk praktik. Dengan kata lain, proses konsumsi yang mencerminkan gaya hidup dan selera budaya lebih pada praktik yang membantu memberikan pemahaman bagi seorang individu maupun orang lain mengenai posisi mereka dalam ruang sosial yang disebabkan adanya dominasi kelas (Bordieu, 1984: 174-175).

Remaja baik mahasiswa atau pekerja bersifat dinamis, senang bergaul atau berinteraksi secara sosial, dan gemar mencoba hal-hal baru atas nama pencarian identitas. Bordieu pun mengungkapkan bahwa gaya hidup individu dapat diamati dari apa saja yang melekat dalam dirinya. Jika direlasikan dengan fenomena eating out, istilah yang layak digunakan adalah "what you eat is what you are" di mana pilihan makanan yang dikonsumsi dapat menunjukkan identitas individu dalam kehidupan sosialnya. Eating out dapat menjadi sebuah sarana untuk bisa diasumsikan sebagai sebuah ranah (arena) tempat bertemunya bentuk-bentuk modal, habitus, dan praktek sosial yang dapat memenuhi hasrat para remaja. Selain itu, pemilihan tempat makan, aksesoris atau gadget yang digunakan pada saat eating out dapat menunjukkan berbagai jenis modal yang dimiliki. 


\section{E. Kesimpulan}

Secara garis besar, penelitian ini menunjukkan bahwa eating out telah mewujud dalam kehidupan remaja Kota Banda Aceh, dan menjadi kegiatan yang sudah biasa dilakukan sehingga menjadi gaya hidup (life style). Berdasarkan tujuan penelitian yang ingin mengetahui bagaimana eating out menjadi salah satu gaya hidup di kalangan remaja Banda Aceh di restoran Canai Mamak KL, maka diperoleh kesimpulan bahwa eating out menjadi gaya hidup karena berhubungan dengan persoalan selera, habitus seseorang, lingkungan, dan interaksi sosial. Eating out juga dapat menjadi arena bertemunya bentuk-bentuk modal, habitus dan praktek sosial remaja.

Berdasarkan pergeseran makna tersebut, konsumsi tidak lagi sekedar berkaitan dengan nilai guna (use value) dalam rangka memenuhi kebutuhan dasar, namun juga berkaitan dengan unsur-unsur simbolik untuk menandai kelas, status atau simbol sosial tertentu. Dalam arti lain, eating out mengekspresikan posisi sosial dan identitas kultural seseorang dalam masyarakat, dimana yang dikonsumsi tidak lagi sekadar objek, tetapi juga makna-makna sosial yang tersembunyi di baliknya. Disini terlihat aktivitas eating out dibeli sebagai gaya ekspresi dan tanda, prestise, kemewahan, dan sebagainya. Artinya ketika mengkonsumsi sesuatu, para remaja mengkomunikasikan banyak hal pada orang lain, termasuk berada di kelompok mana mereka dan berbeda dengan orang lain.

Para remaja tersebut ingin dibedakan dalam berbagai macam lingkungan budaya. Makan di suatu tempat tertentu menjadi penting, karena ada tanggung jawab terhadap munculnya penilaian orang lain terhadap dirinya. Keinginan untuk berbeda merupakan upaya representasi posisi sosial dalam kerangka mekanisme konstruksi penilaian, sehingga eating out juga dijadikan sebagai ajang konstruksi diri yang berkaitan dengan presentasi diri para remaja. Tujuannya adalah untuk memberikan kesan yang baik di hadapan orang lain. Misalnya mereka memilih tampil dengan cara menggunakan aksesoris agar dapat menarik perhatian orang lain. Contohnya seperti menggunakan barang bermerek (branded) atau gadget tertentu.

Dengan demikian prosesi eating out dipengaruhi oleh habitus (internal forces) yang terjadi melalui relasi-relasi kuasa dalam struktur masyarakat yang 
membentuk habitus tentang suatu makanan. Habitus terkait dengan unsur ekonomi dan budaya dimana eating out digunakan untuk menandai pembedaan dengan orang lain. Komoditas makanan (sebagai obyek konsumsi) tidak lagi hanya berdasarkan pada kegunaannya, melainkan juga berkaitan dengan makna-makna yang dibentuk melalui tingkatan kelas sosial sehingga mencirikan kekhasan gaya hidup. Dengan kata lain, dalam diri mereka tertanam referensi nilai-nilai ekonomi budaya yang menumbuhkan suasana gaya dan status sosial dengan cara merekonstruksi kekhasan rasa, suasana dan tempat yang menarik guna memberi pemahaman terhadap orang lain mengenai posisi mereka dalam ruang sosial.

Selain menawarkan aneka menu masakan yang khas Malaysia, restoran Canai Mamak KL juga menghadirkan suasana ruang dan tempat yang sarat dengan unsurunsur modern nan nyaman (baik ditinjau melalui penataan pencahayaan maupun dekorasi ruangan) sehingga membuat pelaku eating out tertarik untuk menghabiskan waktu mereka di restoran tersebut. Hal ini menjadikan eating out berelasi dengan konsumsi ruang (space) dan tempat (place), di mana usaha restoran Canai Mamak KL dalam mengupayakan hal itu dapat mengakibatkan konsumen mengalami rasionalisasi terhadap kebutuhan palsu (false needs) yang diciptakan oleh pihak restoran. Kebutuhan palsu yang diproduksi oleh pihak restoran adalah dengan melakukan komodifikasi terhadap unsur selain makanan (seperti mendekorasi ruang dan tempat) yang didesain sesuai dengan segmentasi sasaran konsumen, yaitu para remaja. Sehingga dalam kasus tersebut, para remaja secara tidak sadar telah mengkonsumsi imaji dan ruang selain dari menu-menu khas Malaysia itu sendiri. 
Aceh Anthropological Journal, Vol. 3, No. 1, hlm: 21-41, April 2019

\section{DAFTAR PUSTAKA}

Assael, Henry. 1984. Consumer Behavior A Strategic Approach. 6th Edition. New York: Thomson-Learning.

Baudrillard, Jean. 1990. Seduction. New York: St. Martin's Press.

Bourdieu, Pierre. 1977. Outline of Theory of Practices. New York: Cambridge University Press.

Bourdieu, Pierre. 1984. Distinction: A Social Critique of the Judgement of Taste. Trans. Richard Nice, Cambridge: Harvard University Press.

Bourdieu, Pierre. 1990. An Introduction to the Work of Pierre Bourdieu: The Practice Theory. (terj. Pipit Maizier dan Saleh Rahmana, Ed.). Yogyakarta: Jalasutra.

Chaney, David. 1996. Lifestyle. (terj. Nuraeni dan Idi Subandy Ibrahim, Ed. Yogyakarta: Jalasutra.

Creswell, John W. 1994. Research Design: Qualitative and Quantitative Approaches. California: Sage Publications, Inc.

Danaher, Geoff, Schirato, Tony and Webb, Jen. 2002. Understanding Bourdieu. London: SAGE Publications Ltd.

Dunn, Robert G. 2008. Identifying Consumption Subjects and Objects in Consumer Society. Philadelphia: Temple Unversity Press.

Featherstone, Mike. 2005. Postmodernisme dan Budaya Konsumen. Terjemahan oleh isbah Zulfa Elizabeth. Yogyakarta: Pustaka Pelajar.

Goodman, Michael K, David Goodman and Michael Redclift (Eds.). 2010. Consuming Space: Placing Consumption in Perspective. Burlington: Ashgate Publishing Company.

Grenfell, Michael (Ed.). 2008. Pierre Bourdieu Key Concepts. Stocksfield: Acumen Publishing Limited.

Hurlock, E.B. 1990. Psikologi Perkembangan Edisi 5. Jakarta: Erlangga.

Jary, David and Julia Jary.1991. Dictionary of Sociology. Glasgow: HarperCollins Publishers.

Kotler, Philip and Amstrong, Gary. 2002. Prinsip-Prinsip Pemasaran. Jakarta: Erlangga

Lee, Martin J. 1993. Consumer Culture Reborn, The Cultural Politics of Consumption. London-New York : Routledge 
Mirnawati. 2011. Analisis Strategi Pemasaran Restoran Canai Mamak Banda Aceh. Jurnal Skripsi. Universitas Muhammadiyah Aceh. (Tidak diterbitkan).

Mowen, John. C dan Minor, Michael. 2002. Perilaku Konsumen. Edisi Kelima. Jilid 1. Edisi Bahasa Indonesia. Terjemahan oleh Lina Salim. 2002. Jakarta: PT Penerbit Erlangga.

Paterson, Mark. 2006. Consumption and Everyday Life. New York : Routledge Limited.

Prakash, Ajaj and V.B. Singh. 2011. "Glocalization In Food Business : Strategies of Adaptation to Local Needs and Demands". Asia Journal of Technology and Management Research Vol. 01 - Issue :01 (Jan - Jun 2011).

Richard Harker, Cheelen Mahar, dan Chris Wilkes. Ed. 2009. (Habitus x Modal) + Ranah = Praktik. Penerjemah: Pipit Maizier. Yogyakarta: Jalasutra Anggota IKAPI.

Warde, Alan and Lydia Martens. 2003. Eating Out: Social Differentiation, Consumption and Pleasure, Cambridge : Cambridge University Press.

Zieleniec, Andrew. 2007. Space and Social Theory. London: SAGE Publications Ltd. 